\title{
Assessment of Hazardous Metal Concentrations in Organs of Selected Game Animals in the Natural Environment
}

\author{
K. Sarpong1, F.R.K. Bonsu2, E. Dartey1,* \\ ${ }^{1}$ Faculty of Science and Environment Education, University of Education, Winneba, Ghana. \\ 2Department of Animal Science Education, University of Education, Winneba, Ghana.
}

\section{ART T C L E D E T A I L S}

\section{Article history:}

Received 20 November 2018

Accepted 16 December 2018

Available online 24 January 2019

\section{Keywords:}

Atomic Absorption Spectrometry

Hazardous Metals

Game Animals

Organs

\begin{abstract}
A B S T R A C T
The study was conducted to determine the levels of hazardous metals in game animals. A total of eighteen (18) animals which comprised six species of three (3) each from the same location were trapped or hunted and sacrificed. Organs analyzed for hazardous metal levels were skin, liver, kidney and heart using Atomic Absorption Spectrometry and content expressed in mgkg-1. The statistical analysis was done with Genstat (2007). Results obtained showed that all the hazardous metals under study were present in the organs at variable concentrations. Lead: skin $(0.18-0.46) \mathrm{mgkg}^{-1}$, liver $(0.03$ - 0.4) $\mathrm{mgkg}^{-1}$, heart $(0.25-0.58) \mathrm{mgkg}^{-1}$ and kidney $(0.381 .12) \mathrm{mgkg}^{-1}$; Cadmium: skin $(0.08-0.58)$ mgkg-1 $^{-1}$ and kidney $(0.09-0.7) \mathrm{mgkg}^{-1}$; Zinc : skin ( $\left.0.46-0.66\right) \mathrm{mgkg}^{-1}$, liver $(90.04-0.82) \mathrm{mgkg}^{-1}$, heart $(0.42-1.21)$ mgkg $^{-1}$ and kidney $(0.43-1.58)$ mgkg $^{-1}$; Copper: skin $(6.13-12.57)$ mgkg-1 $^{-1}$, liver $(5.1$ 9.56) $\mathrm{mgkg}^{-1}$, heart (6.89 - 15.15) $\mathrm{mgkg}^{-1}$ and kidney (7.63 - 24.87) mgkg- $^{-1}$; Iron : skin (9.53 - 26.35) $\mathrm{mgkg}^{-1}$, liver (8.07 -28.08) $\mathrm{mgkg}^{-1}$, heart (13.83 - 46.40) $\mathrm{mgkg}^{-1}$ and kidney $\left(12.43\right.$ - 47.61) $\mathrm{mgkg}^{-1}$. Iron was highly ( $\mathrm{p}<0.05$ ) deposited in all species of animals in the heart $19.88 \mathrm{mgkg}^{-1}, 46.40 \mathrm{mgkg}^{-1}, 40.83$ $\mathrm{mgkg}^{-1}, 13.83 \mathrm{mgkg}^{-1}$ and $41.38 \mathrm{mgkg}^{-1}$ respectively for civet (Civettictis civeta), antelope (Antilocapra americana), grasscutter (Thryonomys swiderianus), hedgehog (Atelerix albiventris) and bush dog (Speothos venaticus) except the bush rat (Rattus fuscipes) that had its highest deposition (46.71 $\mathrm{mgkg}^{-1}$ ) in the kidney. Copper was also highly deposited in animals after iron with higher concentrations in heart and kidney. The highest concentration was recorded for bush rat (Rattus fuscipes) (15.15 mgkg-1) in heart and $24.87 \mathrm{mgkg}^{-1}$ in kidney. Due to bioaccumulation of hazardous metals, care should be taken in patronizing bushmeat obtained from the studied ecosystem since failure could be perilous to the health of consumers as their concentrations are beyond the safe limits for the respective metals. It is further recommended that environmental safety principles for safe disposal of hazardous metals are appropriately carried out.
\end{abstract}

\section{Introduction}

Since the beginning of civilization, game meat has been a main source of meat for humans and the main activity was hunting particularly in developing countries. Subsequently, animal products had formed part of nutrition of humans as they supply phosphorous, vitamins such as $B_{6}$ and $\mathrm{B}_{12}$, iron and niacin to consumers [1, 2]. DEFRA [3] described bushmeat as "meat of wild animal that is hunted for food". Since bushmeat contains high iron content it can be employed to correct nutritional deficiencies such as anaemia in some communities in parts of the world. For example, studies in Madagascar showed that removal of bushmeat from diets expose persons to anaemia [4]. Globally, hunting of bushmeat is widespread and provides populations with income [5] and may serve as an instrument for poverty alleviation [6]. The annual gathering and sale of earthly wildlife is worth billions of dollars [7]. In Ghana the sale of bushmeat is mostly found at the markets and roadside of major highways. Within towns there are also places where bushmeat are sold. A place by name "Atwemonomu" located at Mbrom a suburb of Kumasi is noted for the sale of varieties of wildlife products. Bushmeat gathered and sold are grasscutters, antelope, bush rats, squirrels, porcupine and several others.

Ingredients of some drugs employed by traditional medical practitioners include animal parts such as skins, fat, bone, bile, horns and several others. For example, fats of Calotes versicolor (garden lizard) is used to treat rheumatism while oil/fat of Chamaeleon zeylanica (chameleon) for erectile dysfunction [8].
As part of human diets, contaminated bushmeat especially those with high contents of hazardous metals can adversely affect the health of consumers. The possible sources of introduction of hazardous metals into bushmeat may be contaminated plants in the environment serving as food for the animals. Their presence in the vicinity may be due to natural and anthropogenic processes. It is noted that mercury $[\mathrm{Hg}(0)]$ a poorly soluble and relatively inert gas can be carried in the atmosphere for longer distances. Upon oxidation, $\mathrm{Hg}$ is deposited on the earth and aquatic bodies thus polluting them [9]. Animals drinking polluted water may carry these toxic substances into their bodies. Plants growing in polluted sites absorb hazardous metals through their roots, leaves and store them in their organs. Upon ingestion, these toxic metals are transferred to the animals. Humans feeding on such bushmeat and products may have their health adversely affected. Hazardous metals such as cadmium (Cd), mercury (Hg) and lead $(\mathrm{Pb})$ are viewed as very deleterious and non-essential to living organisms [10]. Lead is harmful to male and female reproductive systems and can change the form of sperm cells [11]. Children delivered to parents exposed to high concentrations of $\mathrm{Pb}$ have high probability of having birth defects. Cadmium has adverse effects on the vicinity and accumulates throughout the food chain showing a menace to human health [12]. Cadmium contamination induce harsh outcome on plants [13]. Hazardous metals bioaccumulate in the body when the rate of elimination is slower than accumulation. Mercury is neurotoxin, nephrotoxin and teratogen [14]. Chronic Cd levels may lead to bone deformation, kidney and cardiovascular problems [15]. Akan et al. [16] reported that meat processing procedures might result to contamination. Spent oil and tyres employed in singeing off hairs of animals introduce hazardous metals and other harmful chemicals into the bushmeat [17].

Bushmeat is treasured throughout Ghana and serves as a delicacy for many dwelling in rural and urban areas. It supplies proteins to consumers, 
creates employment and income for a section of the population. Acquisition of bushmeat is through hunting (gun hunting, dog hunting and net hunting) and setting of traps (i.e. pitfall traps, foot traps, neck traps, etc.). Animals for the study were obtained through setting of traps in the forest closer to farms and not far from auto-mechanic workshops. These farmers apply metal-enriched chemical fertilizers which can be washed to areas where existing plants may absorb these toxic metals. The hazardous metals may be transferred to the animals upon ingestion of contaminated plants. In Ghana there is limited data from literature that addresses the levels of hazardous metals in bushmeat and products, and potential health risk to humans through consumption. The study was embarked upon to assess the hazardous metal content of bushmeat from the Asante Mampong Municipality of the Ashanti region of Ghana.

\section{Experimental Methods}

\subsection{Study Area}

Kofiase is a town, about $13 \mathrm{~km}$ from Mampong the Municipality's capital. Most of the inhabitants are farmers while the rest are traders and school teachers. The map of the study area is indicated in Fig. 1.

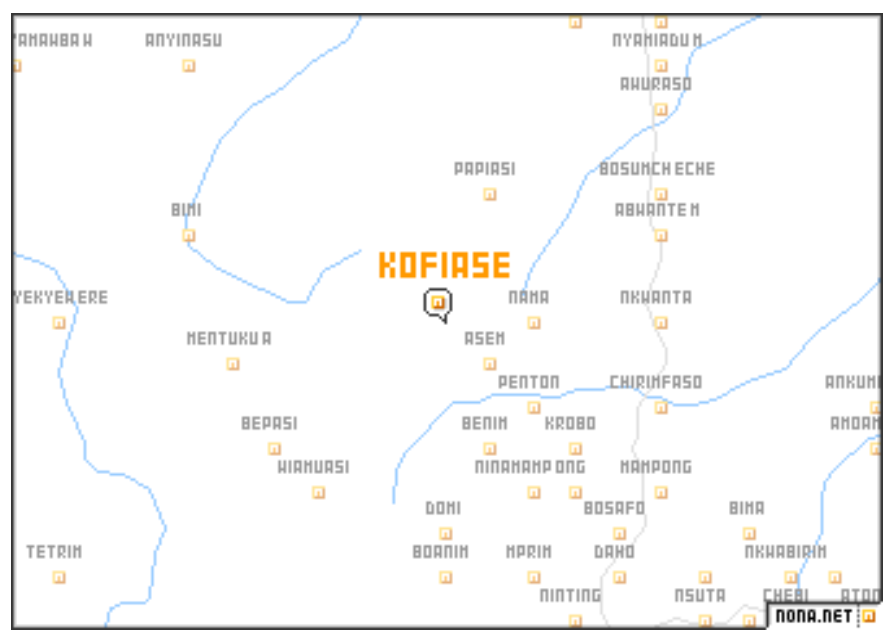

Fig. 1 A map showing the sampling area

\subsection{Collection, Preparation and Analysis of Samples}

Animals were obtained through the setting of traps in a secondary forest at Kofiase near Asante - Mampong. Singeing off the hairs of animals was carried out and three fresh samples each (heart, liver, kidney and skin) were taken. Samples were kept in sterile containers and sent to the Council for Scientific and Industrial Research -Soil Research (CSIR-SRI) at Kwadaso, Kumasi, Ghana for digestion and analysis. Dry Ashing method of digestion was adopted from the protocol of Perkin -Elmer manual for atomic absorption spectrophotometry. A known weight of sample was put into crucibles made of porcelain. The contents of crucibles were dried at $110{ }^{\circ} \mathrm{C}$ and moistened with magnesium nitrate $(50 \% \mathrm{w} / \mathrm{v})$. Ashing started immediately in a controlled muffle carbolated furnace at a temperature of $450{ }^{\circ} \mathrm{C}$ and left overnight to ensure complete oxidation of the sample. The ash of each sample was dissolved in $20 \mathrm{~mL}$ of concentrated nitric $\left(\mathrm{HNO}_{3}\right)$ and perchloric $\left(\mathrm{HClO}_{4}\right)$ acids in a ratio of 9:4 in a $200 \mathrm{~mL}$ digestion tube. It was then heated in a block digester to allow thorough dissolution of ash in acid. Heating continued until the brown fume of nitric acid ceased and the sample turned clear. The digestion was stopped and distilled water added to obtain a total volume of $20 \mathrm{~mL}$. The final solution was filtered through a $0.45 \mu \mathrm{m}$ pore size membrane filter paper (Whatman filter paper No. 41) to obtain a particle-free solution. Heavy metal concentration were determined (in triplicates) using VARIAN SPECTRA AA220 Zeeman Atomic Absorption Spectrometer (AAS) (Varian Canada Inc.). The instrument setting and operational conditions were in accordance with the manufacturers specifications.

\section{Results and Discussion}

\subsection{Lead}

Lead was detected in all the six (6) samples analyzed. The maximum amount of $\mathrm{Pb}$ in the skin was $0.46 \mathrm{mgkg}^{-1}$ which was found in the antelope (Antilocapra americana) whereas the least, $0.18 \mathrm{mgkg}^{-1}$ was in hedgehog (Atelerix albiventris). The rest of skin Pb content were: bush dog (Speothos https://doi.org/10.30799/jespr.150.19050101 venaticus) (0.37 $\left.\mathrm{mgkg}^{-1}\right)$, bush rat (Rattus fuscipes) (0.35 $\left.\mathrm{mgkg}^{-1}\right)$, grasscutter (Thryonomys swiderianus) $\left(0.45 \mathrm{mgkg}^{-1}\right)$ and civet (Civettictis civeta) (0.43 $\left.\mathrm{mgkg}^{-1}\right)$, Table 1 . There was no significant difference in skin $\mathrm{Pb}$ levels between bush dog and bush rat. A Significant difference existed in skin $\mathrm{Pb}$ levels of antelope, civet, bush rat, bush dog and hedgehog. No significant difference existed between $\mathrm{Pb}$ content in civet and grasscutter.

Lead concentrations in the liver of antelope, bush rat, hedgehog and bush dog showed no significance difference. A significant difference was shown between liver of civet, grasscutter and the rest of the animals. The highest $\mathrm{Pb}\left(0.40 \mathrm{mgkg}^{-1}\right)$ and least $\left(0.03 \mathrm{mgkg}^{-1}\right)$ contents were recorded in bush rat and civet respectively. Liver $\mathrm{Pb}$ contents $0.29 \mathrm{mgkg}^{-1}, 0.36$ $\mathrm{mgkg}^{-1}, 0.40 \mathrm{mgkg}^{-1}$ and $36 \mathrm{mgkg}^{-1}$ were for grasscutter, antelope, bush rat and respectively were lower than that observed in a study carried out by Adei and Forson-Adabo [18] which were 5-10 $\mathrm{mgkg}^{-1}, 5.1 \mathrm{mgkg}^{-1}, 3.8$ - 6.3 $\mathrm{mgkg}^{-1}$ for the animals. Also, a research work on the liver Pb levels of grasscutter in four (4) ecotomes in Nigeria was $0.00-0.77 \mathrm{mgkg}^{-1}$ [19], which was higher than the current study of $\mathrm{Pb}\left(0.03-0.40 \mathrm{mgkg}^{-1}\right)$. Current results were lower than the maximum permissible limits (MPL) of $1 \mathrm{mgkg}^{-1}$ for Pb set by Australia-New Zealand Food Authority [20].

The maximum $\mathrm{Pb}\left(0.58 \mathrm{mgkg}^{-1}\right)$ detected in the heart was in bush dog whereas the least of $0.25 \mathrm{mgkg}^{-1}$ was in bush rat. No significant difference existed between heart $\mathrm{Pb}$ content in antelope and grasscutter. There was a significant difference in lead levels in bush dog, hedgehog, bush rat and civet.

Kidney $\mathrm{Pb}$ levels was highest in bush rat. Kidney $\mathrm{Pb}$ levels was in the order: bush rat, $1.12 \mathrm{mgkg}^{-1}>$ bush dog, $0.85 \mathrm{mgkg}^{-1}>$ antelope, $0.65 \mathrm{mgkg}^{-}$ 1 > hedgehog, $0.48 \mathrm{mgkg}^{-1}>$ grasscutter, $0.44 \mathrm{mgkg}^{-1}>$ civet, $0.38 \mathrm{mgkg}^{-1}$. Significant difference in kidney $\mathrm{Pb}$ levels existed between bush dog and the rest of the animals. No significant level existed between kidney levels in civet, grasscutter and Hedgehog.

All the organs with the exception of antelope (heart, $0.55 \mathrm{mgkg}^{-1}$ and kidney, $0.65 \mathrm{mgkg}^{-1}$ ), bush rat (kidney, $1.12 \mathrm{mgkg}^{-1}$ ), grasscutter (heart, $0.53 \mathrm{mgkg}^{-1}$ ]) and bush dog (heart, $0.58 \mathrm{mgkg}^{-1}$, and kidney, $0.85 \mathrm{mgkg}^{-1}$ ) had $\mathrm{Pb}$ levels greater than $0.50 \mathrm{mgkg}^{-1}$ permissible limits (PL) set by European Commission, (EC), 1997. Lead concentrations in the kidney $(0.38-1.12) \mathrm{mgkg}^{-1}$ were lower than $(0.00-1.45) \mathrm{mgkg}^{-1}$ found by Soewu et al. [19] on four (4) ecotomes in Nigeria. The kidney had the highest $\mathrm{Pb}$ amount of $0.38-1.12 \mathrm{mgkg}-1$ in relation to all the organs analyzed. That of heart, liver, and skin were $0.25-0.58 \mathrm{mgkg}^{-1}, 0.03-0.37 \mathrm{mgkg}^{-1}$ and 0.18 $0.46 \mathrm{mgkg}^{-1}$ respectively.

Lead may enter the body by means of feeding, inhalation and skin contact. Once in the body they are stored in body organs [21] and adversely affect the health of the organism. Lead is a neurotoxin and a carcinogen. Lead affects body organs such as the kidney, liver, heart and skin. Also lead $(\mathrm{Pb})$ is detrimental to systems like central nervous system (CNS), genital system, immune system, and several others [22].

Table 1 Concentration of $\mathrm{Pb}$ deposit in mgkg $^{-1}$ in the organs of game animals

\begin{tabular}{lllllllll}
\hline Organ & Civet & Antelope & $\begin{array}{l}\text { Bush } \\
\text { Rat }\end{array}$ & Grasscutter & $\begin{array}{l}\text { Hedge } \\
\text { hog }\end{array}$ & $\begin{array}{l}\text { Bush } \\
\text { dog }\end{array}$ & SEM & LSD \\
\hline Skin & $0.43^{\mathrm{b}}$ & $0.46^{\mathrm{a}}$ & $0.35^{\mathrm{c}}$ & $0.45^{\mathrm{ab}}$ & $0.18^{\mathrm{d}}$ & $0.37^{\mathrm{c}}$ & 0.009 & 0.028 \\
Liver & $0.03^{\mathrm{c}}$ & $0.36^{\mathrm{a}}$ & $0.40^{\mathrm{a}}$ & $0.29^{\mathrm{b}}$ & $0.37 \mathrm{a}$ & $0.36^{\mathrm{a}}$ & 0.017 & 0.053 \\
Heart & $0.37^{\mathrm{cd}}$ & $0.55^{\mathrm{ab}}$ & $0.25^{\mathrm{d}}$ & $0.53^{\mathrm{ab}}$ & $0.43 \mathrm{bc}$ & $0.58^{\mathrm{a}}$ & 0.049 & 0.151 \\
Kidney & $0.38^{\mathrm{d}}$ & $0.65^{\mathrm{c}}$ & $1.12^{\mathrm{a}}$ & $0.44^{\mathrm{d}}$ & $0.48^{\mathrm{cd}}$ & $0.85^{\mathrm{b}}$ & 0.059 & 0.182 \\
\hline
\end{tabular}

*abcd-superscripts in a row denotes significance at $5 \%$

\subsection{Cadmium}

Level of $\mathrm{Cd}\left(0.53 \mathrm{mgkg}^{-1}\right)$ in skin was highest in grasscutter whereas the least level of $\mathrm{Cd}\left(0.08 \mathrm{mgkg}^{-1}\right)$ was in hedgehog (Table 2). No significant difference existed between Cd levels in grasscutter and antelope. Also there was no significant difference between civet, bush rat and hedgehog. A significant difference existed between grasscutter and the other animals. Skin Cd content was higher than the work undertaken in Nigeria which recorded no Cd value [19].

Liver Cd levels in grasscutter in a research done in Arbico, Cd (7.516 mgkg- $^{-1}$ ), Uwa, Cd (3.452 mgkg $^{-1}$ ) and New Benin, Cd (3.923 mgkg $^{-1}$ ) markets indicated higher levels as compared to the present study. Liver Cd amounts were lower than the maximum permissible limits in liver of 0.5 $\mathrm{mgkg}^{-1}$ [23]. Maximum Cd amounts, $0.48 \mathrm{mgkg}^{-1}$ was in antelope whereas the least $0.06 \mathrm{mgkg}^{-1}$ was in civet. Grasscutter, bush rat and hedgehog recorded same Cd level of $0.15 \mathrm{mgkg}^{-1}$. There was a significant difference between $\mathrm{Cd}$ amounts in bush dog and the rest of the animals.

Kidney Cd level $\left(0.70 \mathrm{mgkg}^{-1}\right)$ recorded was maximum in grasscutter. Bush dog had the least Cd level of $0.09 \mathrm{mgkg}^{-1}$. Bush dog, antelope and civet had no significant difference in Cd levels between the kidneys of these animals.

Heart Cd levels had the highest value of $0.58 \mathrm{mgkg}^{-1}$ in grasscutter. Bush rat and grasscutter showed no significance difference in heart of Cd levels. 
Bush dog, antelope, and hedgehog showed no significant difference in heart $\mathrm{Cd}$ content

The content of $\mathrm{Cd}$ in all the organs was highest in kidneys. Kidney $\mathrm{Cd}$ was highest because the organ had metallothionein [24]. Levels of Cd detected were above the FAO/WHO maximum permissible limits (MPL) of $0.05 \mathrm{mg} / \mathrm{kg}$ (WHO, 2000). Cadmium is a toxic chemical without biological function and may cause renal and pulmonary dysfunction, bone and liver damage [25]. It enters the environment through refining and use of cadmium, smelting of copper and nickel, burning of fuel, forest fires and volcanic eruptions.

Table 2 Concentration of $\mathrm{Cd}$ deposit in $\mathrm{mgkg}^{-1}$ in the organs of game animals

\begin{tabular}{lllllllll}
\hline Organ & Civet & Antelope & $\begin{array}{l}\text { Bush } \\
\text { Rat }\end{array}$ & Grasscutter & $\begin{array}{l}\text { Hedge } \\
\text { hog }\end{array}$ & $\begin{array}{l}\text { Bush } \\
\text { dog }\end{array}$ & SEM & LSD \\
\hline Skin & $0.08^{\mathrm{c}}$ & $0.46^{\mathrm{a}}$ & $0.10^{\mathrm{c}}$ & $0.53^{\mathrm{a}}$ & $0.08^{\mathrm{c}}$ & $0.29 \mathrm{~b}$ & 0.034 & 0.110 \\
Liver & $0.06^{\mathrm{d}}$ & $0.48^{\mathrm{a}}$ & $0.15^{\mathrm{c}}$ & $0.15^{\mathrm{c}}$ & $0.15^{\mathrm{c}}$ & $0.38^{\mathrm{b}}$ & 0.015 & 0.047 \\
Heart & $0.03^{\mathrm{c}}$ & $0.38^{\mathrm{b}}$ & $0.56^{\mathrm{a}}$ & $0.58^{\mathrm{a}}$ & $0.30^{\mathrm{b}}$ & $0.32^{\mathrm{b}}$ & 0.074 & 0.160 \\
Kidney & $0.18^{\mathrm{d}}$ & $0.10^{\mathrm{d}}$ & $0.58^{\mathrm{b}}$ & $0.70^{\mathrm{a}}$ & $0.34^{\mathrm{c}}$ & $0.09^{\mathrm{d}}$ & 0.034 & 0.106 \\
\hline
\end{tabular}

*abcd-superscripts in a row denotes significance at $5 \%$

\subsection{Copper}

Skin $\mathrm{Cu}$ was highest in bush dog, (12.57 $\left.\mathrm{mgkg}^{-1}\right)$ whereas hedgehog $\left(6.13 \mathrm{mgkg}^{-1}\right)$ was the least. There was no significant difference between $\mathrm{Cu}$ content registered in antelope and bush dog, civet and bush rat, and grasscutter and hedgehog (Table 3).

Copper was detected in the liver of the organisms. Civet recorded highest $\mathrm{Cu}$ content of $9.56 \mathrm{mgkg}^{-1}$ while least $\mathrm{Cu}$ amount of $5.10 \mathrm{mgkg}^{-1}$ was in grasscutter. No significant difference in $\mathrm{Cu}$ amounts existed between civet and bush rat. Similar observations were made between bush dog and antelope, and hedgehog and grasscutter.

The heart of bush rat contained highest Cu content $\left(15.15 \mathrm{mgkg}^{-1}\right)$ with bush dog having the least $\left(7.32 \mathrm{mgkg}^{-1}\right)$. There was no significant difference between $\mathrm{Cu}$ levels in civet and hedgehog. Also no significant difference existed between antelope, grasscutter and bush dog.

Among all the organs studied the kidney of bush rat $\left(24.87 \mathrm{mgkg}^{-1}\right)$ had highest $\mathrm{Cu}$ content. Least amount of $\mathrm{Cu}$ was in bush dog $\left(8.32 \mathrm{mgkg}^{-1}\right)$. Significant difference existed between kidney $\mathrm{Cu}$ in bush rat and the rest of the organisms. Antelope, bush dog, and hedgehog showed no significant difference in $\mathrm{Cu}$ content.

With the exception of skin Cu levels in grasscutter (6.87 mgkg-1) which was higher than that found in study conducted by Soewu et al (2008), liver $\mathrm{Cu}\left(8.05 \mathrm{mgkg}^{-1}\right)$ and kidney $\mathrm{Cu}\left(13.85 \mathrm{mgkg}^{-1}\right)$ in the current study was almost the same as that found by Soewu et al. (2008) where skin Cu levels was $6.90 \mathrm{ppm}$. Liver Cu levels in grasscutter, $9.56 \mathrm{mgkg}^{-1}$ was lower than that of Adei and Adabo [18] of range 19.2 - $23.1 \mathrm{mgkg}^{-1}$.

Copper is abundant in our surroundings and released through natural and human activities. Forest fires and decaying of vegetation are the natural means by which $\mathrm{Cu}$ enters the ecosystem. Anthropogenic means such as mining, manufacturing and use of phosphate fertilizers and many others account for greater amounts of $\mathrm{Cu}$ in the vicinity. Humans need trace quantities of $\mathrm{Cu}$ for good health, for example it aids $\mathrm{Fe}$ in the formation of red blood cells. Copper is a component of some blood proteins. Blood protein erythrocuprein, exists in erythrocytes, and plays a role in oxygen metabolism [26, 27]. Lack of $\mathrm{Cu}$ results in osteoporosis, poor growth, depigmentation of hair and anaemia. Lack of $\mathrm{Cu}$ results in osteoporosis and anaemia.

Table 3 Concentration of $\mathrm{Cu}$ deposit in $\mathrm{mgkg}^{-1}$ in the organs of game animals

\begin{tabular}{lllllllll}
\hline Organ & Civet & Antelope & $\begin{array}{l}\text { Bush } \\
\text { Rat }\end{array}$ & Grasscutter & $\begin{array}{l}\text { Hedge } \\
\text { hog }\end{array}$ & $\begin{array}{l}\text { Bush } \\
\text { dog }\end{array}$ & SEM & LSD \\
\hline Skin & $8.40^{\mathrm{b}}$ & $11.80^{\mathrm{a}}$ & $9.10^{\mathrm{b}}$ & $6.87^{\mathrm{c}}$ & $6.13^{\mathrm{c}}$ & $12.57^{\mathrm{a}}$ & 0.274 & 0.844 \\
Liver & $9.56^{\mathrm{a}}$ & $7.2^{\mathrm{b}}$ & $5.60^{\mathrm{cd}}$ & $5.10^{\mathrm{d}}$ & $8.69^{\mathrm{a}}$ & $6.58^{\mathrm{bc}}$ & 0.370 & 1.14 \\
Heart & $10.13^{\mathrm{b}}$ & $7.8^{\mathrm{c}}$ & $15.15^{\mathrm{a}}$ & $6.89^{\mathrm{c}}$ & $10.35^{\mathrm{b}}$ & $7.32^{\mathrm{c}}$ & 0.478 & 1.47 \\
Kidney & $11.92^{\mathrm{c}}$ & $7.63^{\mathrm{d}}$ & $24.87^{\mathrm{a}}$ & $15.83^{\mathrm{b}}$ & $8^{8.68^{\mathrm{d}}}$ & $8.32^{\mathrm{d}}$ & 0.53 & 1.64 \\
\hline
\end{tabular}

*abcd-superscripts in a row denotes significance at 5\%

\subsection{Iron}

The iron concentration in the skin was highest $(\mathrm{p}<0.05)$ in the grasscutter (26.35 $\mathrm{mgkg}^{-1}$ ) as compared to that of antelope (15.62 $\mathrm{mgkg}^{-1}$ ) which was higher than $14.23 \mathrm{mgkg}^{-1}, 13.9 \mathrm{mgkg}^{-1}$ and $9.53 \mathrm{mgkg}^{-1}$ in bush dog, civet and hedgehog respectively. Concentration of iron recorded from liver of game animals ranged from $28.08 \mathrm{mgkg}^{-1}$ to $8.07 \mathrm{mgkg}^{-1}$. Concentration of iron in the liver of the antelope $(28.08 \mathrm{mg}$ ) was highest $(p<0.05)$ and lowest $(p<0.05)$ in the bush rat $\left(8.69 \mathrm{mg} \mathrm{kg}^{-1}\right)$ and hedgehog $\left(8.07 \mathrm{mgkg}^{-1}\right)$ (Table 4$)$. The concentration of iron in the heart was also highest $(\mathrm{p}<0.05)$ for the antelope $\left(46.4 \mathrm{mgkg}^{-1}\right)$, however, bush dog and https://doi.org/10.30799/jespr.150.19050101 grasscutter had figures $41.38 \mathrm{mgkg}^{-1}$ and $40.83 \mathrm{mgkg}^{-1}$ respectively which were close to that recorded by the antelope. The lowest $(\mathrm{p}<0.05)$ iron concentration in the heart was recorded in the hedgehog $\left(13.83 \mathrm{mgkg}^{-1}\right)$. Iron concentration in the kidney was highest $(\mathrm{p}<0.05)$ for the bush rat (47.61 $\mathrm{mg} \mathrm{kg}^{-1}$ ) followed by $32.25 \mathrm{mgkg}^{-1}>21.80 \mathrm{mgkg}^{-1}>20.45 \mathrm{mgkg}^{-1}>$ $12.43 \mathrm{mgkg}^{-1}>10.28 \mathrm{mgkg}^{-1}$ respectively for antelope, bush dog, hedgehog and civet. The iron accumulation in the heart was relatively high as compared to the accumulated concentrations in the other organs of same animal and different game animals considered and thus made the heart appeared as the preferred organ for accumulation of iron than the other organs. This is contrary to the observation that the liver is natural source of $\mathrm{Fe}$ and other essential elements and thus might have higher heavy metals and other contaminants that have a propensity to accumulate in the liver tissues [18]. Iron ingested by animals is mainly obtained from the feed (forage and formulated diet) materials as influenced by the particular geographic location. Consumption of minute quantities of soil is purposely done to obtain iron if dietary sources are deficient in some cases [26]. The ingestion of soil is stimulated physiologically if levels are low. Iron is particularly important to the animal due to its paramount role played in haematopoiesis and a host of biochemical reactions, principally in connection with enzymes of electron transport chain [26]. Iron occurs in blood serum in a protein (transferrin) responsible for Fe transport to all body parts. Ferritin and haemosiderin proteins are the storage compounds for iron in the spleen, liver, kidney and bone marrow. The research area is closer to human activities (vehicle mechanic repair shops) where a lot of deposits of metals from rejected vehicles part are discarded which finally decompose to become part of the soil. This was expected to increase Fe accumulation in organs of these game animals from ingestion of forages and soils from the catchment area. However, concentrations recorded in this study are lower or within recommended range of 20 - 80 $\mathrm{mgkg}^{-1}$ and thus suggest that level observed as not toxic to the game animals. This corroborates the observation made that Fe toxicity is not a common problem in animals probably due to reduced sensitivity of absorptive organs to high body concentrations [28]. Nonetheless, game animals such as grasscutter and bush dog found closer to human habitation had relatively higher levels of Fe. Accumulation levels in the organs of the game animals are also relatively higher as compared to the concentrations of domestic animals under intensive production system [29].

Table 4 Concentration of Fe deposit in mgkg-1 $^{-1}$ in the organs of game animals

\begin{tabular}{lllllllll}
\hline Organ & Civet & Antelope & $\begin{array}{l}\text { Bush } \\
\text { Rat }\end{array}$ & Grasscutter & $\begin{array}{l}\text { Hedge } \\
\text { hog }\end{array}$ & $\begin{array}{l}\text { Bush } \\
\text { dog }\end{array}$ & SEM & LSD \\
\hline Skin & $13.9^{\mathrm{c}}$ & $15.62^{\mathrm{b}}$ & $11.2^{\mathrm{d}}$ & $26.35^{\mathrm{a}}$ & $9.53^{\mathrm{e}}$ & $14.23^{\mathrm{c}}$ & 0.274 & 0.844 \\
Liver & $12.61^{\mathrm{c}}$ & $28.08^{\mathrm{a}}$ & $8^{8.69^{\mathrm{d}}}$ & $22.03^{\mathrm{b}}$ & $8.07^{\mathrm{d}}$ & $23.15^{\mathrm{b}}$ & 0.370 & 1.14 \\
Heart & $19.88^{\mathrm{d}}$ & $46.4^{\mathrm{a}}$ & $26.9^{\mathrm{c}}$ & $40.83^{\mathrm{b}}$ & $13.83^{\mathrm{e}}$ & $41.38^{\mathrm{b}}$ & 0.478 & 1.47 \\
Kidney & $10.28^{\mathrm{d}}$ & $21.80^{\mathrm{c}}$ & $47.61^{\mathrm{a}}$ & $32.55^{\mathrm{b}}$ & $12.43^{\mathrm{d}}$ & $20.45^{\mathrm{c}}$ & 0.530 & 1.64 \\
\hline
\end{tabular}

*abcd-superscripts in a row denotes significance at 5\%

\subsection{Zinc}

The concentration of zinc in the skin of the game animals ranged from $0.46 \mathrm{mgkg}^{-1}$ to $0.66 \mathrm{mgkg}^{-1}$ and were not significantly different $(\mathrm{p}>0.05)$ from each other. The $\mathrm{Zn}$ content in the liver ranged from $0.04 \mathrm{mgkg}^{-1}$ to $0.82 \mathrm{mgkg}^{-1}$ and differed significantly $(\mathrm{p}<0.05)$ among the game animals. The $\mathrm{Zn}$ content in the liver of antelope, bush rat and bush dog were not significantly $(p>0.05)$ different but were all higher $(p<0.05)$ as compared to grasscutter and hedgehog with civet recording the lowest $(\mathrm{p}<0.05) \mathrm{Zn}$ concentration in the liver. The $\mathrm{Zn}$ accumulation in the heart also ranged from 0.4 to $1.21 \mathrm{mgkg}^{-1}$. Antelope and bush rat had higher $\mathrm{Zn}$ accumulation in the heart as compared to bush dog which also had a higher concentration relative civet, grasscutter and hedgehog. Civet, grasscutter and hedgehog had similar $\mathrm{Zn}$ content in the heart. The $\mathrm{Zn}$ accumulation in the kidney ranged from 0.43 to $1.58 \mathrm{mgkg}^{-1}$. Bush rat recorded the highest $(\mathrm{p}<0.05)$ kidney $\mathrm{Zn}$ content as compared to the other game animals considered. Grasscutter and antelope had higher $(\mathrm{p}<0.05)$ kidney $\mathrm{Zn}$ amount in relation to bush dog, civet and hedgehog which had similar concentrations in the kidney. The Zn liver levels were within the safe permissible limits of $50 \mathrm{mgkg}^{-1}$ of the WHO/FAO [30].

Table 5 Concentration of $\mathrm{Zn}$ deposit in $\mathrm{mgkg}^{-1}$ in the organs of game animals

\begin{tabular}{|c|c|c|c|c|c|c|c|c|}
\hline Organ & Civet & Antelope & $\begin{array}{l}\text { Bush } \\
\text { Rat }\end{array}$ & Grasscutter & $\begin{array}{l}\text { Hedge } \\
\text { hog }\end{array}$ & $\begin{array}{l}\text { Bush } \\
\text { dog }\end{array}$ & SEM & LSD \\
\hline Skin & 0.56 & 0.66 & 0.58 & 0.46 & 0.56 & 0.61 & 0.117 & 0.36 \\
\hline Liver & 0.04 & $0.82^{\mathrm{a}}$ & $0.80^{\mathrm{a}}$ & $0.53^{\mathrm{b}}$ & $0.45^{b}$ & $0.74^{\mathrm{a}}$ & 0.053 & 0.163 \\
\hline Heart & $0.55^{c}$ & $1.21^{\mathrm{a}}$ & $1.20^{\mathrm{a}}$ & $0.55^{c}$ & $0.40^{c}$ & $1.02^{\mathrm{b}}$ & 0.054 & 0.166 \\
\hline Kidney & $0.53^{\mathrm{c}}$ & $0.80^{\mathrm{b}}$ & $1.58^{\mathrm{a}}$ & $0.99^{b}$ & $0.43^{c}$ & $0.65^{c}$ & 0.1 .07 & 0.233 \\
\hline
\end{tabular}

*abcd-superscripts in a row denotes significance at $5 \%$ 


\section{Conclusion}

Bushmeat is considered a delicacy by many Ghanaians. Sales of bushmeat are observed along highways in many parts of Ghana. The presence of hazardous metals in the bushmeat should be of concern to Ghanaians since they bioaccumulate. Traders involved in bush meat and products and other stakeholders including the Metropolitan, Municipal and District Assemblies (MMDA's) should be made to form associations where members can be educated on the toxic effects of hazardous metals through durbars, seminars, colloquia etc. The traders should be given a license. Bye- laws should be enacted so that bushmeat sold within their territories are screened for the presence of hazardous metals before sale. MMDA's should form task force to monitor this to ensure that dealers in bushmeat and products comply. The task force should visit markets, "chop bars" etc. Hunters and traders who fail to comply should be made to pay fines. Vegetation, water and soils within territories where bushmeat are obtained should be analysed for hazardous metal content. This is necessary because the animals depend on these (water, vegetation and soils) for their survival. Animals ingesting contaminated vegetation, drinking contaminated water and interacting with contaminated soil may have hazardous metals which they can pass to human.

\section{References}

[1] J.O. Igene, K.I. Okoro, P.A. Ebabhamiegbebho, S.E. Evivie, A study assessing some metal elements contamination levels in grasscutter (Thryonomys swinderianus Temminck) meat, Int. J. Biotech. Food Sci. 3(5) (2015) 63-69.

[2] P.G. William, Nutrient composition of red meat, 2007. http://ro.Uow.edu.au/hbspapers/48 (Accessed on: 18.08.2016)

[3] DEFRA, Facts about 2006. www.defra.gov.uk/animalh/illegali/topics/bushmeat.htm (Accessed on: 05.02.2017)

[4] FAO, How does bushmeat contribute to nutrition? Bushmeat Sourcebook, Nutritional and Consumer Protection Division, Rome, 2015.

[5] E.L. Bennett, Is there a link between wild meat and food security? Conserv. Biol. 16 (2002) $590-592$.

[6] E.J. Milner-Gulland, E.L. Bennett, Group Wild meat: The big picture, Trends Ecol. E. 18 (2003) 351-357.

[7] D. Brown, Bushmeat and poverty alleviation: implications for Development policy, Wildlife policy Briefings Overseas Development Institute, London, 2003.

[8] J.G. Robinson, E.L. Bennett, Hunting for sustainability in tropical forests, Colombia University Press, New York, 2000.

[9] S.K. Jana, N.R. Madhu, A review zoo-ethno-medico-biological studies and human welfare, Int. J. Curr. Res. Aca. Rev. 2(12) (2014) 179-187.

[10] EMEP Status Report, Heavy metal trans boundary pollution of the environment, Nowegian Meteorological Institute, Norway, 2014.

[11] D.Z. Doganoc, K.S. Gacnic, Lead and cadmium in meat and organs of game in Slovenia, Bull. Environ. Contam. Toxicol. 54(1) (1995) 166-170.
[12] OSHA, Occupational Safety and Health Administration, US Department of Labour, Lead in Construction, USA, 2004.

[13] APHA, AWW, WEF, Standard Methods for the examination of water and wastewater, $20^{\text {th }}$ Ed., American Publish Health Association, Washington DC. 1998.

[14] T. Baszynski, Interference of $\mathrm{Cd}^{2+}$ in functioning of the photosynthetic apparatus of higher plants, Acta Soc. Bot. Pol. 55(2) (1986) 291-304.

[15] UNIDO, Technical Report, Environmental and health assessment in two smallscale gold mining areas, Indonesia final report on Sulewasi and Kalimantan, Indonesia, 2004.

[16] R.A. Goyer, T.W. Clarkson, Toxic effects of metals, In: Casarett and Doullis Toxicology: The basic science of poisons, Sixth Edn., C.D. Klaassen, Ed., McGraw-Hill, New York, 2001, pp. 811-867.

[17] J.C. Akan, F.I. Abdu, O.A. Irahman, Sodipo, Y.A. Chiroma, Distribution of heavy metals in the liver, kidney and meat of beef, mutton, caprine and chicken from Kasuwan Shanu Market in Maiduguri Metropolis, Borno State, Res. J. Appl. Sci. Eng. Technol. 2(8) (2010) 743-748.

[18] W. Okiei, M. Ogunlesi, F. Alabi, B. Osiughwu, Sojinrin, Determination of toxic metal concentrations of flame treated meat products, ponmo, Afr. J. Biochem. Res. 3(10) (2009) 332-339.

[19] E. Adei, K. Forson- Adaboh, Toxic ( $\mathrm{Pb}, \mathrm{Cd}, \mathrm{Hg})$ and essential ( $\mathrm{Fe}, \mathrm{Cu}, \mathrm{Mn}$ ) metal content of liver tissue of some domestic and bush animals in Ghana, Food Addit. Contam. B 1 (2008) 100-105.

[20] D.A. Soewu, O.M. Agbolade, R.Y. Oladunjoye, I.A. Ayodele, Bioaccumulation of heavy metals in cane rat (Thryonomys swinderianus) in Ogun State, Nigeria. J. Toxicol. Environ. Health Sci. 6(8) (2014) 154-160.

[21] L. Järup, Hazards of heavy metal contamination, Br Med. Bull. 68 (2003) 16782.

[22] N. Zahra, I. Kalim, M. Mahmood, N. Naeem, Perilous effects of heavy metals contamination on human health, Pak. J. Anal. Environ. Chem. 18(1) (2017) 117.

[23] FAO/WHO, Report of the 32nd Session of the committee of food additives Contaminants, Beijing, Peoples Republic of China. 2000.

[24] R.P. Smith, H.C. Hodge, Clinical toxicology of commercial products, $5^{\text {th }}$ Edn. Williams and Wilkins, Baltimore, 1984, pp. III-78.

[25] D.F. Khater, H.N. Soultan, N.A. Abrosaa, Hazard evaluation of some insecticides and heavy metals residues in duck carcasses, Benha Veter. Med. J. 22(2) (2011) 87-94.

[26] K. Wishart, Increased Micronutrient requirements during physiologically demanding situations: review of the current evidence, Vitam. Miner. 6 (2017) 166-173.

[27] Carolyn D. Berdanier, Handbook of nutrition and food, CRC Press, Taylor and Francis Group, Boca Raton, 2014.

[28] H.J. Ampofo, B.O. Emikpe, T.N. Asenso, D.A. Asare, R. Yeboah, T.A. Jarikre, A Jagun-Jubril, Hunting practices and heavy metals concentrations in fresh and smoked wild meats in Kumasi, Ghana, Jour. Res. Forest. Wildlife Env. 9(3) (2017) 43-49.

[29] St. Leontopoulos, N. Gougoulias, D. Kantas, L. Roka, Ch. Makridis, , Heavy metal accumulation in animal tissues and internal organs of pigs correlated with feed habits, Bulg. J. Agric. Sci. 21 (2015) 693-697.

[30] FAO/WHO, Codex alimentarius commission standard programme, Codex Committee on Food Additives and Contaminants, 24th Session, Hague, Netherlands, 1992. 